\title{
Tumor of granular breast cells: Clinicopathological study in the population of the General Hospital of Mexico "Dr. Eduardo Liceaga"
}

\author{
Avissai Alcántara-Vázquez ${ }^{1,2 *}$, Alberto Sánchez-Lara1,2, and Mercedes Hernández-González ${ }^{1,2}$ \\ ${ }^{1}$ Surgical Pathology Unit, General Hospital of Mexico "Dr. Eduardo Liceaga"; ${ }^{2}$ Faculty of Medicine, Universidad Nacional Autónoma de México \\ (UNAM). Mexico City, México
}

\begin{abstract}
Objective: The objective of the study was to study the incidence of granular cell tumor of the breast (GCTB) in the population of the General Hospital of Mexico, a lesion that is clinically and radiologically confused with breast carcinoma. Materials and methods: Search the database of the Surgical Pathology Unit, the cases of Tumor of Granular Breast Cell, during the period 2002 to 2020. Results: Two cases of GCTB were found in women aged 59 years and 64 years, respectively. One of the cases was discovered in the mammary skin, a product of infiltrating ductal carcinoma mastectomy and the other was a granular cell tumor (GCT), which was clinically considered breast carcinoma. Hence, lumpectomy and sentinel lymph node dissection were performed. The two tumors showed clinical and histopathological features consistent with benign GCTB. Conclusion: GCTB occurs in $0.1 \%$ of breast tumors and $6 \%$ of GCT. It is clinically and radiologically confused with breast carcinoma, therefore, histopathological studies together with immunohistochemistry are valuable tools, in the correct diagnosis, which prevents an inappropriate treatment.
\end{abstract}

Key words: Granule cell tumor. Immunohistochemistry. Mother.

\section{Introduction}

Granular cell tumor of the breast (GCTB) is a rare lesion, accounting for $<1 \%$ of breast tumors and $6 \%$ of all reported cases of granular cell tumor (GCT) 1 . It usually occurs in the soft tissues ${ }^{2}$, but also occurs in the skin, vulva, larynx, bronchus, esophagus, stomach, appendix, rectum, anus, bile ducts, pancreas, urinary bladder, uterus, brain, and pituitary gland. It mainly affects the head and neck and especially the tongue, where Weber identified it in 1854. Subsequently, in 1926, a tumor was described in the breast by Abrikossoff who referred to the lesion as myoblastoma, considering its origin to be muscular ${ }^{3}$. It is currently assumed as a tumor originating from Schwann cells or perineural cell precursors, which grow in lobular breast tissue, all as a result of immunohistochemical $(\mathrm{IHC})$ findings ${ }^{4}$.

GCTB must be differentiated from breast carcinoma to avoid inappropriate treatment. However, it is necessary to consider that some GCTBs occur concurrently with infiltrating ductal carcinoma (IDC) ${ }^{5}$. The tumor has also occurred in mastectomy scars ${ }^{6}$. This tumor is more frequent in middle-aged, in dark skinned subjects, and premenopausal women. In men, this lesion is extremely rare ${ }^{3}$.

\section{Methods and patients}

A descriptive, retrospective, and observational study was carried out by reviewing the database of the

\section{Correspondence:}

*Avissai Alcántara-Vázquez

E-mail: avissai@ hotmail.com NC-ND license (http://creativecommons.org/licenses/by-nc-nd/4.0/).
Date of reception: 02-03-2021

Date of acceptance: 09-06-2021 DOI: 10.24875/HGMX.21000019
Available online: 18-10-2021 Rev Med Hosp Gen Mex. 2021;84(4):169-173 www.hospitalgeneral.mx 
Surgical Pathology Unit of the General Hospital of Mexico "Dr. Eduardo Liceaga," conducted from 2002 to 2020. In this review, two cases of GCTB were found. Based on these cases, the following data were obtained: clinical history, histopathological report, slides, and paraffin blocks for complementary sections if necessary.

\section{Case 1}

GAM, a 64-year-old woman, who underwent surgery for breast carcinoma outside the General Hospital of Mexico, came to this institution for review of slides and subsequent treatment as required. At the surgical pathology unit, 21 slides were received, 17 of which were stained with hematoxylin and eosin and four slides showed an IHC reaction. Microscopic examination confirmed the diagnosis of IDC. The tumor showed lymphovascular invasion, with no lymph node metastasis. On IHC, estrogen and progesterone receptors were negative, CerB2 was positive +++ and p53 was positive at $40 \%$.

A $1 \mathrm{~cm}$ tumor in diameter with infiltrative borders was found in the tissue of the breast excised for carcinoma; it consisted of nests of histoid-like cells, with a large, eosinophilic and granular cytoplasm, and pustulo-ovoid bodies of Milian (POB) (Fig. 1). The nucleus was central, ovoid, with homogeneous chromatin, without mitotic activity, and without necrosis. The stroma was fibrous with numerous capillary vessels. The IHC performed on this tumor was positive for $\mathbf{S 1 0 0}$ protein, CD68, vimentin, and neuron-specific enolase.

Follow-up of the patient was not possible, as she did not return for further evaluation.

\section{Case 2}

SMC, a 59-year-old woman, with a history of smoking from the age of 18 until 20 days before hospital admission, allergy to penicillin, tubal ligation at the age of 39 , and type 2 diabetes mellitus, treated with hypoglycemic agents for 1 year before admission.

Gyneco-obstetric history: Menarche at 14 years of age, sexual debut at 25 years of age, last menstrual period at 52 years of age. Six gestations, four pregnancies and two miscarriages.

Her condition began when she underwent routine mammogram, which was assessed as Breast imagining reporting and Data System (BIRADS 4), for which reason she was referred to the General Hospital of Mexico.

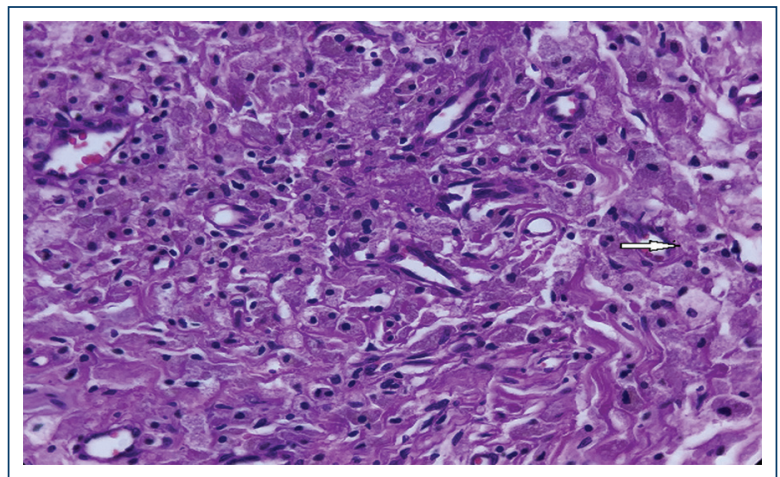

Figure 1. Proliferation of large cells with eosinophilic granular cytoplasm, and Pustulo-ovoid bodies of Milian (POB) (arrow) $(\times 200)$.

Physical examination of the breasts revealed that they were symmetrical, pendulous, without tumors, or enlarged regional lymph nodes. The rest of the physical examination was reported to be within normal limits.

During her stay at the hospital, routine laboratory tests were conducted, which revealed hyperglycemia of $184 \mathrm{mg} / \mathrm{dl}$. Based on these data, a diagnosis of probable left breast carcinoma was made. A new mammogram was performed, which revealed fibrocystic changes and a study category of BIRADS 2 . Thus, it was decided to perform a tru-cut biopsy, which revealed a GCTB. A lumpectomy and sentinel lymph node dissection were then performed. The histopathological result of the breast was the same as the biopsy and the sentinel lymph node was negative for metastasis. The patient has been followed up with periodic clinical check-ups, and after 5 years, no recurrence has been found.

At the surgical pathology unit, a fragment of breast tissue was received, ovoid in shape, $4 \times 2 \times 1 \mathrm{~cm}$ in size, yellow color, with fibroadipose appearance and a soft consistency. On section, there was an ovoid lesion, $2.5 \mathrm{~cm}$ in the longest axis, with infiltrative borders, white in color, and firm consistency.

In microscopic terms, the tumor consisted of nests or cords of large cells, with large, eosinophilic, granular cytoplasm, ovoid nuclei, with small nucleoli, without cellular atypia, necrosis, or mitotic activity (Fig. 2). IHC was positive for protein S 100 (Fig. 3), CD68 (Fig. 4), vimentin, and neuron-specific enolase and was negative for estrogen and progesterone receptors.

\section{Results}

Microscopically speaking, the two cases present tumors consisting of nests, cords, or sheets of large cells, 


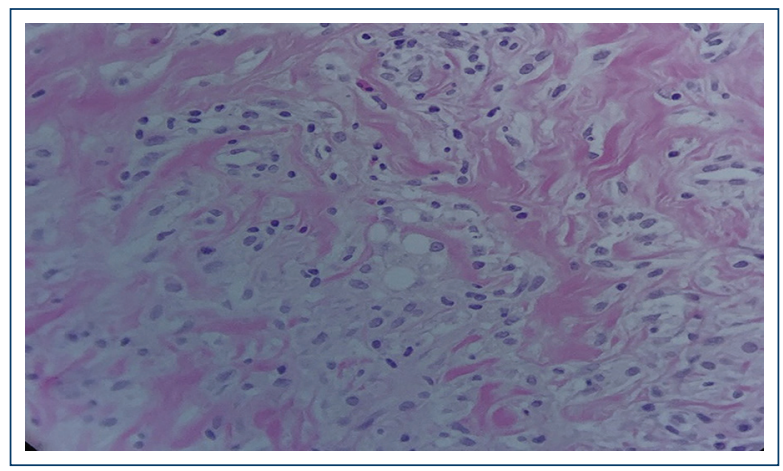

Figure 2. Granular cell tumour with histoid-like cells, large cytoplasm, homogeneous ovoid nucleus and inconspicuous nucleolus, all in a fibrous stroma. $(\times 250)$.

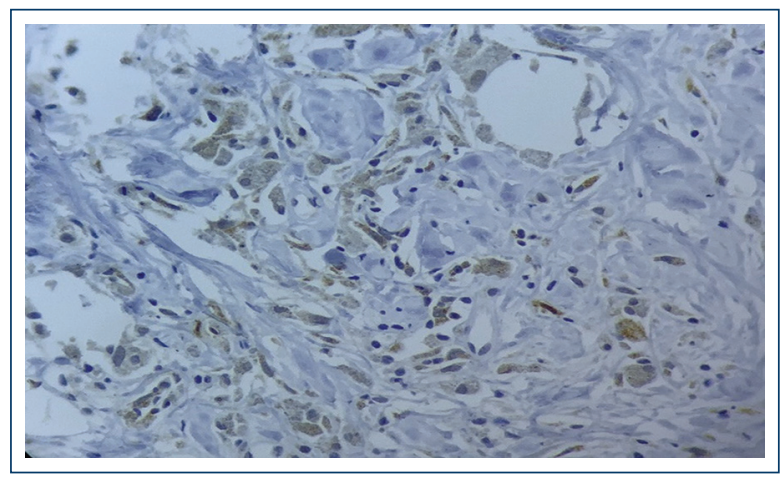

Figure 3. S-100 protein reaction in a granular cell tumour $(\times 250)$.

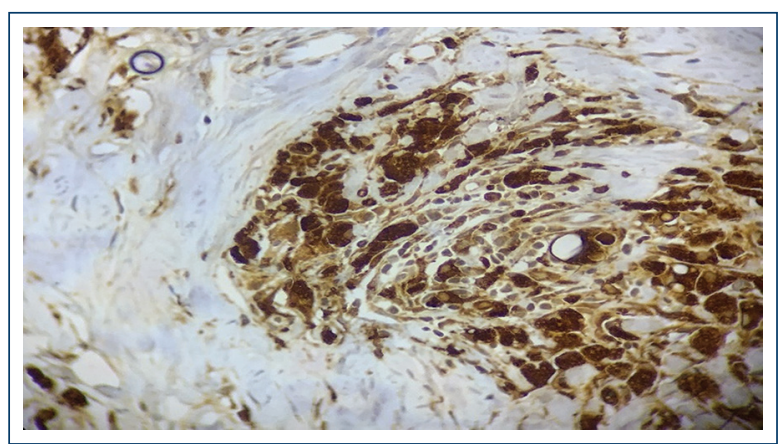

Figure 4. CD68 positive in a granular cell tumour $(\times 250)$.

with large granular eosinophilic cytoplasm,without nuclear or celular atypia, no necrosis or mitotic activity. One of the cases show intracitoplasmic Milian bodies. As for $\mathrm{IHC}$, results were positive for $\mathrm{S} 100$ protein, $\mathrm{CD68}$, vimentin, neuron-specific enolase, and negative for estrogen and progesterone receptors.
Histopathological and IHC findings in both cases indicated that the GCTs of the breast were benign.

\section{Discussion}

GCTB is a rare lesion, initially described as a muscle tumor (myoblastoma) and subsequently, due to IHC and ultrastructural findings, considered to originate from interlobular stromal cells (Schwann cells) and spread through the cutaneous branches of the supraclavicular nerve ${ }^{7}$, whereby lesions may arise predominantly in the upper inner quadrant; this assertion is currently debated ${ }^{8}$.

A subgroup of non-neural GCTs, negative for $S 100$ and positive for CD68 and CD10, has been identified that may not derive from neural tissue ${ }^{9}$. These GCTs harbor an ALK gene fusion and stain positively with IHC for anaplastic lymphoma kinase ${ }^{10}$.

GCT is rare, as Lack et al..$^{11}$ in a 32-year study of surgical material from a single institution, found a frequency of $0.03 \%$. As for GCTB, a frequency of $0.1 \%$ of breast tumors has been reported'. In our 19-year study of surgical material from the pathology department, we found two cases in a review of 405,293 histopathological reports.

GCTB can arise in any location, including the four quadrants, the axilla and the nipple ${ }^{8}$; most frequently in the upper inner quadrant of the left breast ${ }^{12}$. In our study, the affected side was known in only one case, which was the upper outer quadrant of the left breast.

GCTB usually occurs in premenopausal women, but a wide age range has been described from 15 years to 74 years of age. In men, the frequency is $9.8 \%$ of $\mathrm{GCTB}^{13}$. In our review, the two patients were in their sixth decade of life.

In $70 \%$ of cases of GCTB, it presents as a palpable, firm, usually painless mass, although some patients have reported pain, pruritus, skin retraction, and reactive lymphadenopathy ${ }^{8,14}$. Our two cases were asymptomatic.

Mammograms can show a variety of presentations, such as irregularly shaped focal masses, blurred contours, and spiculated margins ${ }^{15}$. In some cases, it has benign features such as well circumscribed rounded masses without microcalcifications ${ }^{16}$. In one of our cases, the mammogram showed a nodular lesion, with blurred contours and spiculated margins, which led us to consider the diagnosis of breast cancer.

Histologically speaking, GCTB is characterized as infiltrative, non-encapsulated, consisting of nests, cords, or sheets of polygonal, occasionally 
spindle-shaped cells with large, finely granular, eosinophilic cytoplasm. Many of them have POB in the cytoplasm; these are large haloed granules, representing enlarged lysosomes. The tumor cells have relatively small nuclei with dense chromatin and central localisation ${ }^{17,18}$. Our cases present the diagnostic histological data, and in one of them, $\mathrm{POB}$ were identified.

In the ultrastructure, GCT granules appear as lysosomal complexes, in the form of dense bodies. It is suggested that these granules originate from a mechanism of internal invagination of the cell membrane, similar to the phenomenon that occurs in the axonal myelination process, with the invaginations being digested by phagolysosomes, giving rise to lysosomal complexes and intracytoplasmic myelin bodies ${ }^{19}$. This explains the reactivity of GCTs to CD57, an antigen related to a myelin-bound glycoprotein ${ }^{20}$. Also to myelomonocytic antigen (CD68), a marker of a lysosomal protein ${ }^{21}$. The lack of basement membrane in GCTs explains the different reaction to laminin in these tumors compared to schwannomas/neurofibromas, which have basement membrane ${ }^{22}$. No ultrastructural studies were performed in our cases.

By immunohistochemistry $(\mathrm{IHC})$, benign and malignant GCTs react positively to $\mathrm{S} 100$ protein, CD68, neuron-specific enolase, CD57, inhibin, calretinin, TFE3, SOX10, CD56, PGP9.5, and vimentin and negatively to estrogen and progesterone receptors ${ }^{23-25}$. Our cases were positive for $\mathrm{S} 100$ protein, CD68, and neuron-specific enolase and negative for estrogen and progesterone receptors.

The vast majority of GCTB are benign, only $1-2 \%$ are malignant ${ }^{26,27}$. Tumors can be subclassified into benign, atypical, and malignant, according to their histological findings. The first system was developed in 1998 by Fanburg-Smith ${ }^{28}$, using six datasets: necrosis, mitosis (more than 2x10 strong dry fields), spindle-shaped tumor cells, nuclear pleomorphism, prominent nucleolus, vesicular nucleus, and elevated nucleus/cytoplasm ratio. Lesions without any of these findings fall into the benign category, with one or two positive data are called atypical and three or more data are classified as malignant and therefore with a poor prognosis. Other factors with an unfavorable prognosis are cell proliferation index (Ki 67) of more than 10\%, p53 positivity, tumor size $>5 \mathrm{~cm}$, and advanced age of the patient ${ }^{29}$. Our patients were in their sixth decade of life, their tumors measured $<3 \mathrm{~cm}$ and their histopathological findings were benign.
Genetic study of GCTB shows mutation in one of the two genes, ATP6AP1 or ATP6AP2. These genes act as $\mathrm{pH}$ regulators in Schwan cells; when impaired they stimulate oncogenesis through phosphorylation of PDGFR-B, SKF, and STAT-5. They also cause acidification of vesicles, altered endocytosis, and accumulation of intracytoplasmic granules. This correlates with the discovery of eosinophil granules in the cytoplasm. The study suggests that the genes act as tumor suppressors and that, when $\mathrm{pH}$ regulation is broken, they may contribute to oncogenesis ${ }^{30}$. Our cases did not undergo cytogenetic study.

The drastic difference in treatment and clinical course between GCTB and breast carcinoma makes it necessary to differentiate between these two conditions. Treatment of GCTB involves complete resection with tumor-free margins, which is curative ${ }^{31}$. With wide excision, recurrence is $2-8 \%$ and increases to $21-50 \%$ with incomplete ablation ${ }^{32}$. If GCTB undergoes malignant transformation, treatment is similar to that of breast carcinoma, with a poor prognosis. Our cases were benign tumors that were completely removed; one by radical mastectomy, as the GCTB had IDC. The other case, with a diagnosis of probable breast carcinoma, underwent lumpectomy with sentinel lymph node dissection. In the follow-up of this patient, no recurrence has been demonstrated after 5 years.

\section{Conclusion}

This tumor is rare; however, it must be known and identified to diagnose it properly and avoid confusing it with breast cancer.

\section{Funding}

The authors declare that they have not received funding for this study.

\section{Conflicts of interest}

The authors declare no conflicts of interest.

\section{Ethical disclosures}

Protection of human and animal subjects. The authors declare that no experiments were performed on humans or animals for this study.

Confidentiality of data. The authors declare that they have followed the protocols of their work center on the publication of patient data. 
Right to privacy and informed consent. The authors have obtained the written informed consent of the patients or subjects mentioned in the article. The corresponding author is in possession of this document.

\section{References}

1. Pujani M, Singh K, Raychaudhuri S, Agarwal C, Khandelwal A, Menia R, et al. Granular cell tumor breast masquerading as a malignancy citologically: A rare case presenting a diagnostic dilemma. Indian J Surg Oncol. 2020;11:321-4

2. Mathews JB, Mason Al. Oral cell myoblastoma. An immunohistochemical study. J Oral Pathol 1987;9:341-5.

3. Castillo LM, Martínez HA, Cardoso RT, López DM. Granular cell tumor in breast: A case report. Cancer Targets Ther 2017;9:245-8.

4. Beccelli R, Perugini M, Gasparini G, Cassoni A, Fabiani F. Abrikossoff's tumors. J Craniofac Surg 2001;121:78-81.

5. Trant A, Kallakury BV, Carter J, Wolf BC, Ross JS. Coexistence of granular cell tumor and ipsilateral infiltranting ductal carcinoma of the breast. South Med J 1997;90:1149-51.

6. Rosso R, Scelsi M, Carnevali L. Granular cell traumatic neuroma: A lesión ocurring in mastectomy scars. Arch Pathol Lab Med 2000;124: 709-11.

7. Cirso G, Nubila BD, Ciccia A, De Camilli E, Vicini E, Trentin C, et al. Granular cell tumor of the breast: Molecular pathology and clinical management. Breast J. 2018;24:778-82.

8. Brown AC, Audisio RA, Regitning P. Granular cell tumor of the breast. Surg Oncol. 2011;20:97-105.

9. Fernández FA, Cassarino DS, Riveiro-Falkenbach E, Rodriguez-Peralto JL, Fernandez-Figueras MT, Monteagudo C. El tumor cutáneo de células granulares no neurales dérmicas es un fibroma de la vaina de la raíz dérmica de células granulares. J Cutan Pathol. 2017: 44:582-7.

10. Cohen JN, Yeh I, Jordan RC, Wolsky RJ, Horvai AE, McCalmont TH, et al. Cutaneous non neural granular cell tumors harbor recurrent ALK gene fusions. Am J Surg Pathol. 2018;42:1133-42.

11. Hammas N, Faterm HE, Jayis S, Hafid I, Fikri G, El Houari A, et al. Granular cell tumor of the breast: A case report. J Med Case Rep. 2014;8:465-8.

12. Lack EE, Worsham GF, Callihan MD, Crawford BE, Klappenbach S, Rowden G, et al. Granular cell tumor: A clinicopathologic study of 110 patients. J Surg Oncol. 1980;13:301-16.

13. Boulat J, Mathoulin MP, Vachuret A. Granular cell tumor of the breast. Ann Pathol. 1994:14:93-100.

14. Sijan KJ, Barthier S, Trichot C. Granular cell breast cancer: a rare misleading lesión. Diagn Interv Imaging. 2015;96:287-9.
15. Jagannathan DM. Benign ganular cell tumor of the breast: a case report and literatura review. Radiol Case Report. 2015;10:1116-8.

16. Al-Balas M, De Leo A, Serra M, Santini D, Taffurelli M. Granular cell tumor of the breast: a rare presentation of a breast mass an ederly female with a subsequent breast cancer diagnosis. SAGE Open Med Case Rep. 2019;7:313-5.

17. Papalas J, Wyllie JD, Dash RC. Recurrence risk and margyn status in granular cell tumor of the breast: A clinicopathologic study of 13 patients. Arch Patho Lab Med. 2001;135:890-5.

18. Epstein DS, Pashael S, Hunt E Jr., Fitzpatrick JE, Golitz LE. Pustulo ovoid bodies of Milian in granular cell tumors. J Cutan Pathol. 2007;34:405-9.

19. Mittal KR, True LD. Origino f granular cell tumor intracelular myelin formation with autodigestion. Arch Pathol Lab Med. 1988;112:302-3.

20. Smole J, Konrad K, Kerl H. Granular cell tumor contain myelin associated glycoprotein. An immunohistochemical study usingLeu 7 monoclonal antibody. Virch Arch Pathol. 1985;406:1-5.

21. Kurtin PJ, Bonn DM. Immunohistochemical demostration of the lysosome associated glycoprotein CD68 in granular cell tumor and schwanomes. Hum Pathol 1994;25:1172-8.

22. Miettinen M, Lechtonen E, Ekblom P, Lehto VP, Virtanen I. Histogenesis of granular cell tumor: An immunohistochemical and ultrastructural study. J Pathol. 1984;142:221-9.

23. Rekhi B, Jambhekar NA. Morphologic spectrum immunohistochemkcal análisis and clinical features: a study from tertiary referal cancer center. Ann Diag Pathol. 2010;14:162-7.

24. Schoolmeester JK, Lastra RR. Granular cell tumor over express TFE3 without corollary gen rearrangement. Hum Pathol. 2015;46:1242-3.

25. Ingram DL, Mossler JA, Snowhite J, Leight GS, McCarty KS Jr. Granular cel tumor of the breast. Steroid receptor análisis and localization of carcinoembrionario antigen, myoglobina and S100 protein. Arch Pathol Lab Med. 1984;108:897-901.

26. Jardines L, Cheung L, LiVolsi V, Hendrickson S, Brooks JJ. Malignan granular cell tumor: report 0 case and review of literatura. Surgery. 1994:116:49-54.

27. Moten As, Zaho H, Wu H, Farma JM. Granular cell tumor: clinical features and longterm survival. J Surg Oncol. 2018;118:891-7.

28. Fanburg-Smith JC, Meis Kindblom JM, Fante R, Kindblom LG. Malignant garnular cell tumor of soft tissues: diagnostic criteria and clinicopathologic correlation. Am J Surg Pathol. 1998;22:779-94.

29. Vera SF, García A, Froufe A, Corell E, Ruiz F, Mayordomo F. Tumor de células granulares de la piel mamaria. Estudio morfológico de 2 casos mostrando reactividad a inhibina. Rev Esp Patol 2000;3:433-40.

30. Pareja F, Brandes AH, Basili T, Selenica P, Geyer FC, Fan D, et al. Loos of mutations in ATP6AP1 and ATP6AP2 in granular cell tumors. Nat Commun. 2018:9:3533.

31. Qureshi NA, Tahir M, Carmichael AR. Granular cell umors of the soft tissues: A case report and literatures review. Int Sem Surg Oncol. 2006;3:21-6.

32. Kuo F, Lally K, Lewis M, Vahidi K. Granular cell tumor in male breast mimicking breast carcinoma. BJM Case Report. 2019;12:1-2. 